\title{
マイクロチャンネル内流れにおける疎水・親水粗さの影響
}

\section{Effect of Hydrophilic or Hydrophobic random surface roughness in microchannel flow}

\author{
○学 宮城 惊矢（首都大） 正 小方聡（首都大）
}

\author{
Junya MIYAGI, Tokyo metropolitan University, Mlnamiosawa, Hachioji-shi, Tokyo \\ Satoshi OGATA, Tokyo metropolitan University, Mlnamiosawa, Hachioji-shi, Tokyo
}

\begin{abstract}
Recently, there has been a growing interest to develop microscale devices that can manipulate and transport relatively small volumes of fluids. In this study, we investigated the influence of wall surface conditions and polymer addition on microchannel flow. We measured the pressure drop in microchannel flow for three patterns of channel height $h=$ $100,50,20 \mu \mathrm{m}$. Tested channel surface roughness are $\mathrm{Ra}=0.2,0.8,1.6 \mu \mathrm{m}$. The experiment showed that the pressure drop increased with increase of channel surface roughness as in the case of both hydrophilic and hydrophobic surface. For polymer solution, the pressure drop decreased in all roughness. Drag reduction rate was increased with the increase of surface roughness.
\end{abstract}

Key Words: Pressure drop, Laminar flow, Microchannel, Surface roughness, Hydrophobicity

\section{1. 緒言}

近年 MEMS 技術の発達に伴いマイクロ流体デバイスが注目 され，その流体力学的観点からの性能向上が求められている. 性能向上のためには, マイクロスケール場における流体挙動 の把握が非常に重要となっている. それ故マイクロスケール における実験は数多く行われている.しかしそれらの実験結 果の多くは, 層流における圧力損失の測定結果がナビエ・ス トークスの厳密解と一致せず, 未だにマイクロスケール場に おける正確な実験データの傾向を掴むに至っていない. その 原因として，流路壁面の表面性状や流路作製時寸法誤差，供 試流体中の不純物の影響, 実験データ測定の困難さ等が考え られる(1)

一般的にマイクロスケール流れは層流であるため, 表面粗 さ等の表面性状の影響を受けない. しかし流路寸法の微小化 と共に表面の影響は増大するため, 流路壁面の表面粗さによ りその圧力損失が変化する等, マクロスケールでの特性がマ イクロスケールに適応できないことがある.

一方, 微小管内流れにおいて, 高分子水溶液や界面活性剂 水溶液の圧力損失が減少することが知られている ${ }^{(2)}$. この要 因として，固液界面の挙動が流れに大きな影響を与えること が指摘されているが,これらに関する実験的研究はほとんど 成されてない. マイクロスケールの流れにおいて上記添加剂 の流動特性はマク口な流れと異なることが予想され，それら を明らかにすることは非常に興味深い.

よって, 本研究は, 流路壁面の表面性状(親水性・疎水性 の表面粗さ)がマイクロ流れに与える影響および高分子の供 試流体一の添加がマイクロ流れに及ぼす影響を実験的に明 らかにすることを目的とする。

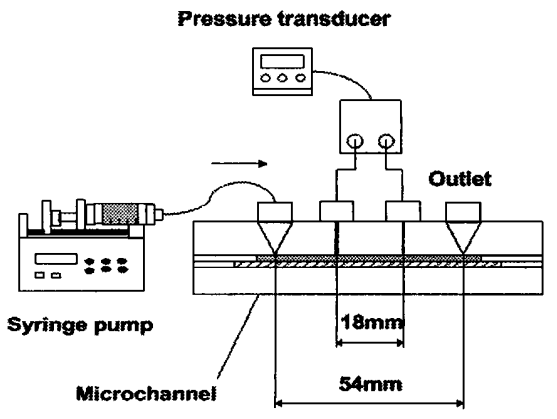

Fig.1 Schematics of pressure drop measuring device

\section{2. 実験装置お゙よひ実験方法}

図 1 は実験装置の概略である. 実験装置はマイクロチャン ネル, シリンジポンプ, 圧力変換器から構成される.

図 2 にマイクロチャンネルの構成図を示す. マイクロチャ ンネルはステンレス鋼 (SUS304)製で 4つの層からなるサン ドイッチ構造で構成されており，8つのボルトを同一トルク で締め付けている. スペーサーで作られる流路長さは $64 \mathrm{~mm}$, 流路幅は $2 \mathrm{~mm}$ である．スペーサーの厚さは $100,50,20 \mu \mathrm{m}$ の 3 種類を用意することで, 流路の高さを変更することがで きる. 試験壁は, 親水性・疎水性ともに, 表面粗さ $\mathrm{Ra}=0.2$, $0.8,1.6$ の 3 種類を用意した. $\mathrm{Ra}=0.2,0.8$ は機械加工, $\mathrm{Ra}=1.6$ はサンドブラストにより製作した. 疎水性表面は供試 金属表面にトリアジンチオールを真空蒸着させ被膜するこ とで作製した．その膜厚は 50〜 100nm であり， Ra 及ぼす影 響はほとんどない.トップカバーは $\mathrm{Ra}=0.8 \mu \mathrm{m}$ である. 流 路側壁となるスペーサーの Ra は不明であるが, 流路のアス ペクト比が最大で 0.001 であるので側面のRaが流れに及ぼす 影響はほとんどないと考えられる.トップカバーにある圧力 測定孔間の距離は $18 \mathrm{~mm}$, 流体の入口と出口間の距離は $54 \mathrm{~mm}$ である．供試流体は蒸留水，5ppm ポリエチレンオキシド

（SE-70, 分子量 580000）水溶液, である。供試流体の温度 はマイクロチャンネルの出ロで測定した.

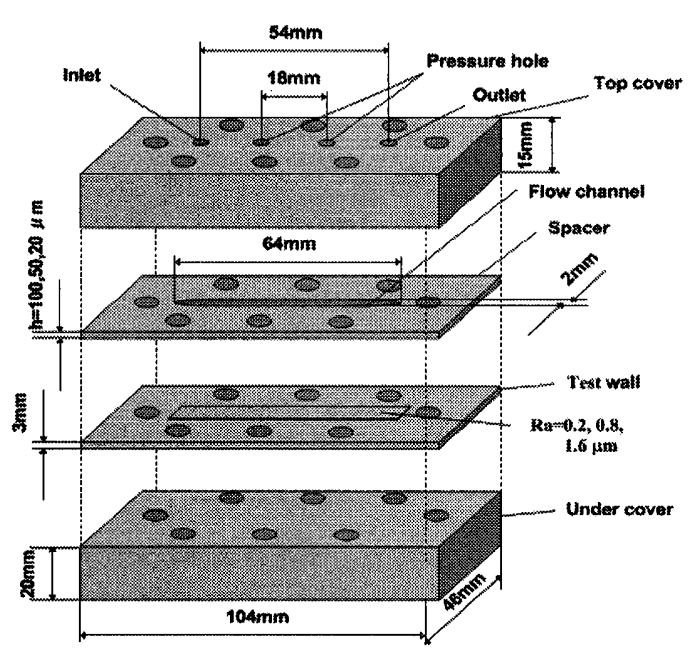

Fig.2 Details of test microchannel 


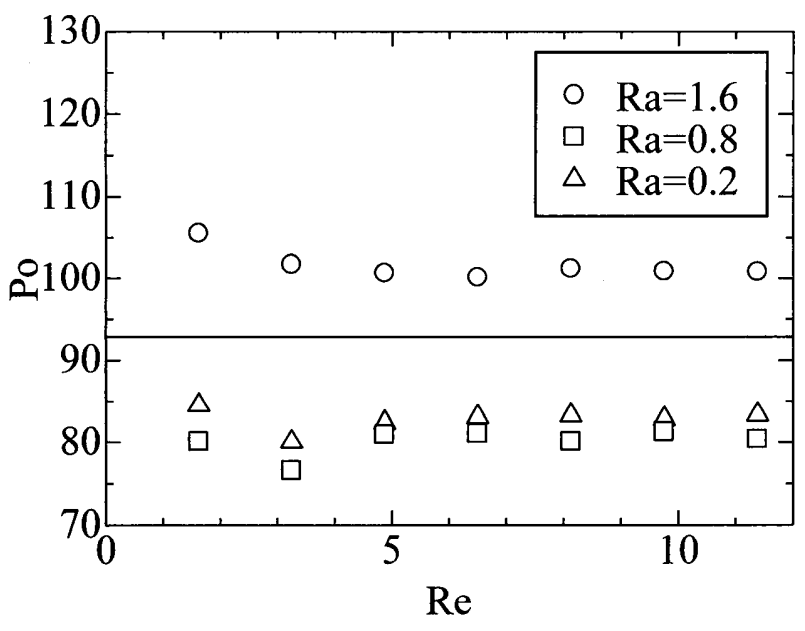

Fig. 3 Poiseuille number of hydrophilic surface roughness

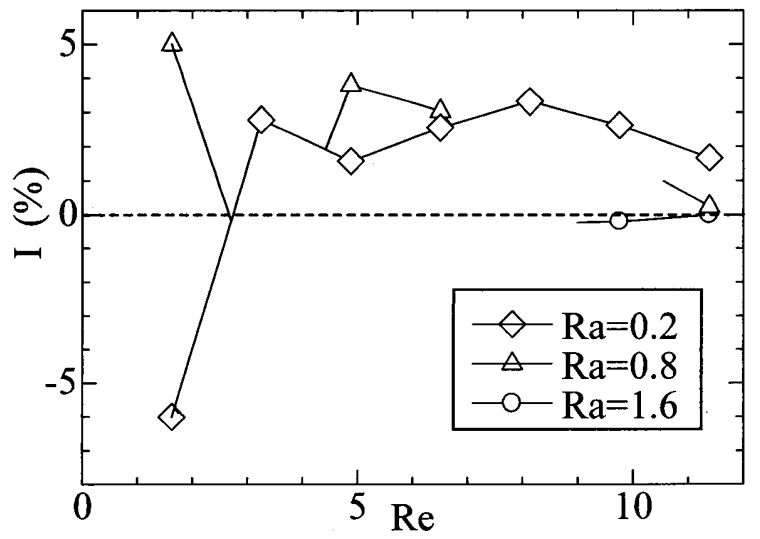

Fig. 4 Effect of hydrophobicity on Poiseuille number

\section{3. 結果・考察}

図 3 に流路高さ $h=50 \mu \mathrm{m}$ における親水性粗さ壁面の実験 結果をポアズイユ数 Po で示す. 図中の実線は理論值である. 図 3 より, $\mathrm{Ra}=0.2 ， 0.8$ の Po 数に明確な違いは見られないが, これらより粗さが粗い $\mathrm{Ra}=1.6$ は Po 数が大きくなった.この ことは, 従来から指摘されているように, 表面粗さの影響で マイクロチャンネルの圧力損失が増加したことによる.

図 4 に疎水性表面粗さの結果を示す. 結果は $h=50 \mu \mathrm{m}$ にお ける親水と疎水の Po 数の増加率 $I$ で示してある. 増加率 $I$ は 以下のように定義される.

$$
I=\frac{P o_{A}-P o_{B}}{P o_{B}} \times 100(\%) \quad \cdots(1)
$$

ここで, $P o_{A}$ : 疎水性の場合のポアズイユ数, $P o_{B}$ : 親水性の 場合のポアズイユ数である， Re が 5 以上の範囲では，各粗 さとも疎水性のほうが親水性よりも若干圧力損失が増加し ていることが分かる.

図 5 に高分子水溶液のポアズイユ数増加率 $I$ と $\operatorname{Re}$ の関係 を示す。ここでの増加率の定義は式 (1) と同じであるが, 式 中の $\mathrm{Po}_{A}$ は高分子水溶液のポアズイユ数を, $P o_{B}$ :蒸留水の ポアズイユ数とした．図 5 より，高分子水溶液はいずれの粗 さでも圧力損失の低减が見られることがわかる。これは Ushida $ら^{(4)}$ の結果と一致する.また，若干ではあるが、粗さ の増加とともに抵抗減少率も増加した.

図 6 に親水性の場合の相対粗さとPo 数の関係を示してい る. 相対粗さの増加とともにポアズイユ数も増加した．この 傾向は従来の研究と一致する.

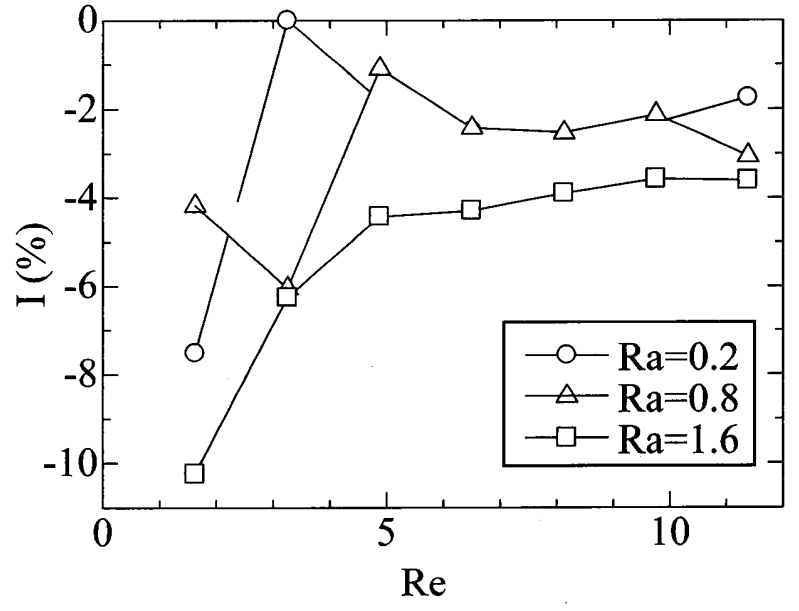

Fig.5 Effect of polymer on Poiseuille number

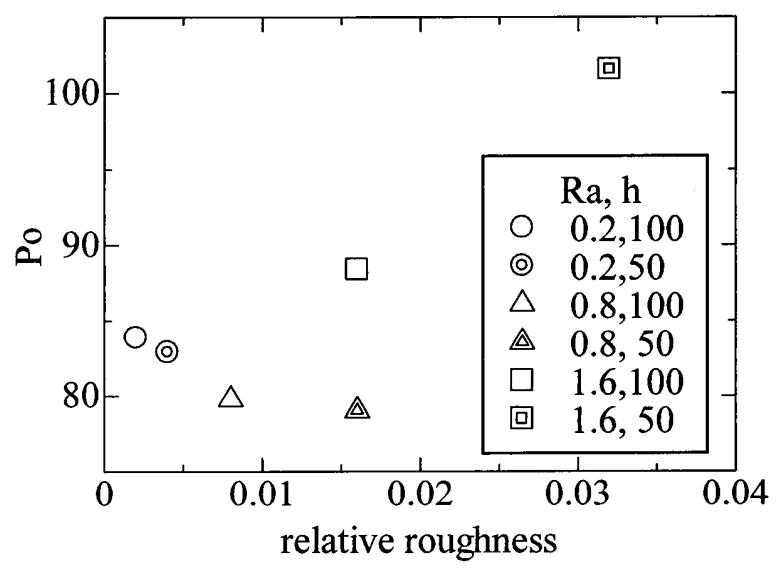

Fig.6 Relationship between relative roughness and Poiseuille number

\section{4. まとめ}

流路壁面の表面性状や高分子の供試流体への添加がマイ クロ流れに及ぼす影響を実験的に明らかにした。その結果， 表面粗さ Ra の増加とともに圧力損失が増加した．また，表 面を疎水性にした場合，抵抗低減は生じず逆に圧力損失が増 加する.一方，高分子を添加した場合，全ての粗さにおいて 抵抗が低減した。この抵抗低減率は粗さの増加とともに増加 した.

5. 引用文献

(1) I.Papautskya, B.K. Galeb, S. Mohantya, T.A. Ameelc, and A.B. Frazierd, Effects of rectangular microchannel aspect ratio on laminar friction constant, Proceedings of SPIE 3877 (1999) pp. 147-158.

(2) Watanabe, K., Ogata, S., Hirose, A., Kimura, A., "Flow Characteristics of the Drag Reducing Solid Wall," Journal of Environment and Engineering, Vol. 2, No. 1, (2007), pp. 108-114.

（3）小方聡, 清水圭吾, 撥水性微細構造による抵抗減少 効果に関する研究, 日本機械学会論文集, 75-758, B (2009) , 1960-1966.

(4) Akiomi Ushida, Tomiichi Hasegawa, Takatsune Narumi' "Drag reduction for liquid flow through micro-apertures" Journal of Non-Newtonian Fluid Mechanics. 165(2010) pp. 1516-1524. 